\title{
紙パルプ産業における環境保全状況 (II) \\ 一大気污染防止に関する規制と対策の推移一
}

日本製紙連合会・環境保全委員会

\section{Environmental Protection in the Pulp and Paper Industry for these ten years from 1971 to 1980}

\author{
IAPAN PAPER ASSOCIATION
}

Keywords : Environmental protection

\begin{abstract}
要 約
この報售は紙パルプ産業における大気活染防止の规 制々対策について, 昭和 46 作から10 年間の推移をア

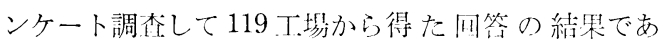
る。

この 10 年間に国の規制は各污染物質とも数次の改 足強化が行われ，自治体による、来せ規制もこれに迫 従して厳しくなってきている。公害防止協定で大気污 染防止に関しての取沈めをしている工場数は，问笭工 場の $58 \%$ \%隹いる。

これらの規制強化に対㐫するため 10 作開に投資さ れた金額は536 偲门に達しており，その主体は $\mathrm{SO}_{\mathrm{x}}$ 対策が $52 \%$ ，ばいじん対策が $40 \%$ となっている。ま た，投資額の約 $55 \%$ は目油ボイラー，33\%は问収 ボイラーの対策設倠に伐用されている。投資額の年:度 推移では昭和 50 体渡がピーク上なっており，これは この時期に $\mathrm{SO}_{\mathrm{x}}$ の総望規制実施やK值改正があって 脱硫装置の設置に多額の扱資が行われたためである。 54〜55年度の投資が再増加しているのは最近の重油ボ イラーから石炭燃燒への䡮换と, 脱硫装琶の増加等が 罗因である。
\end{abstract}

\section{1. はじめに}

紙パルプ産業では，パルプの蒸解および紙・板紙の 乾燥などの熱源に多㹃の蒸気孛侹用しており，多くの 工場では自家発電設倩を経て各工科!へその蒸気を供給 している関係から，而油または石炭ボイラーを設置し

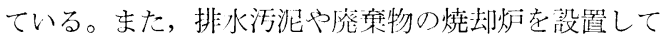
いる工場も多い。さらにパルプ工埸には廃液同収ボイ 昭和 59 作 (1984) 5 ر
表 1 アンケート集計場

\begin{tabular}{|c|c|c|c|}
\hline 規 模 別 & $\begin{array}{l}\text { 四筩 } \\
\text { 工場数 }\end{array}$ & $\begin{array}{l}\text { 集 } \\
\text { 工場数 }\end{array}$ & 備 \\
\hline 大企業 & 92 & 92 & \\
\hline 打小企業 & 27 & 22 & $\begin{array}{lll}\text { ばい煙施設なし } & (2) \\
\text { 無 記 } & \text { 記 }\end{array}$ \\
\hline 合棓 & 119 & 114 & \\
\hline
\end{tabular}

ラーや石灰燒成炉が使用されている。

これらの施設から排出するばい煙は大気污染防止法 の規制を受け，さらに自治体の条例，行政指導や公害 防止協定によって上乗せ規制を受けている工場が多 い。汒の改定によって逐次規制の強化が進み，それに 伴って自治体の上乗せも悠しくなってきたために，紙 パルプ業界では排水対策に次いで巨額の設備投資を行 ってこれに対処してきている。

昭和 46 年からの 10 年閒における規制と対策に関寸 る今回のアンケート調査で。大気関係では大企業は56 社 92 工場, 中小企は 27 社 27 工場, 合引 119 工場の 回答が得られたので，その集忛結果について述べる (表 1 )。

\section{2. 規制の推移について}

\section{1 国の規制}

2.1.1 硫黄酸化物 $\left(\mathrm{SO}_{\mathrm{x}}\right)$

硫黄酸化物についてはK值でばい煙発生施設からの 排出を制限する方法と，K值による排出制限では環境 基準が維持されない高污染地域について，排出量その ものを制限する総量規制による方法とで規制が央施さ れている。 


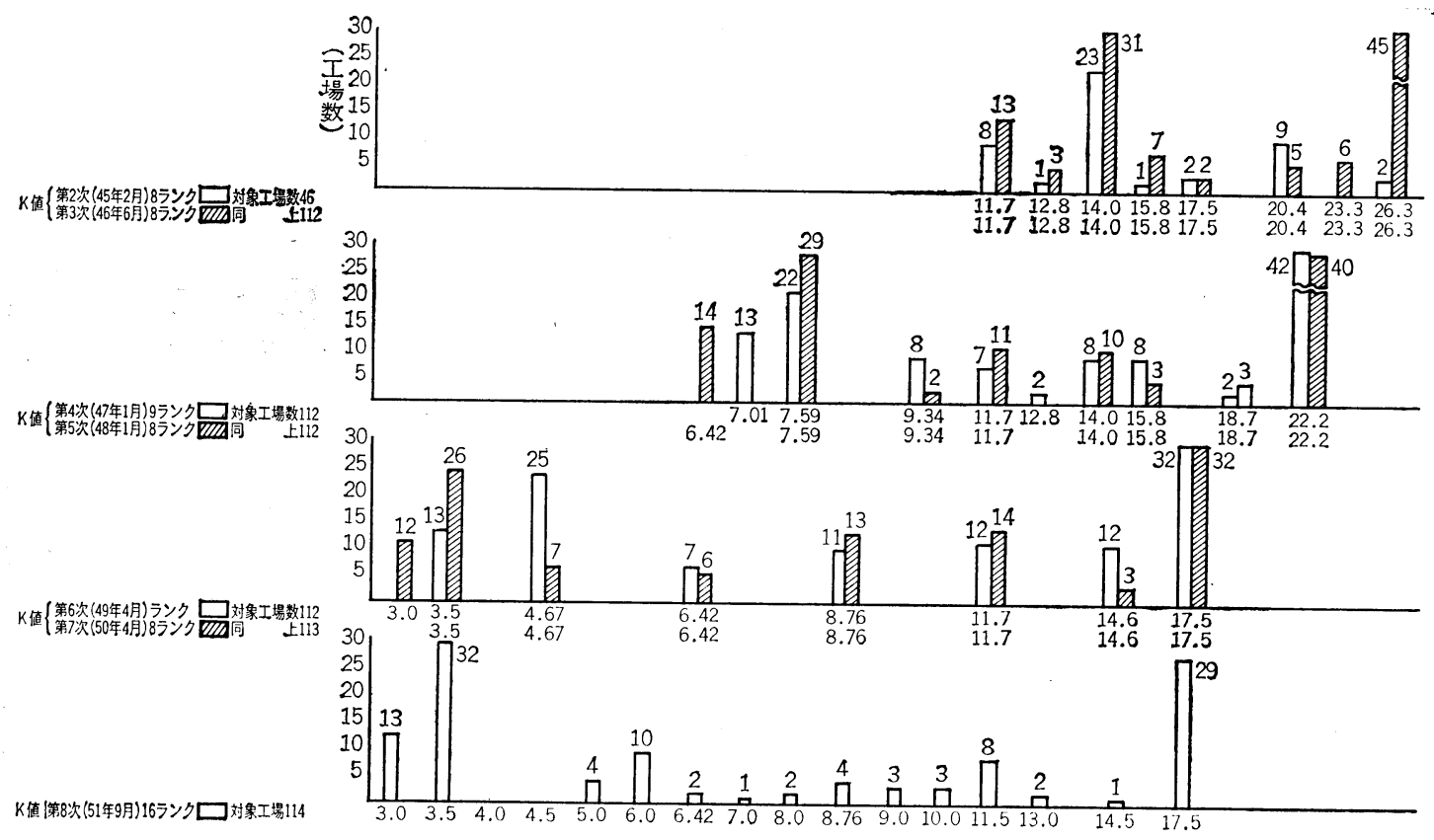

図 $1 \mathrm{~K}$ 值規制 の推移
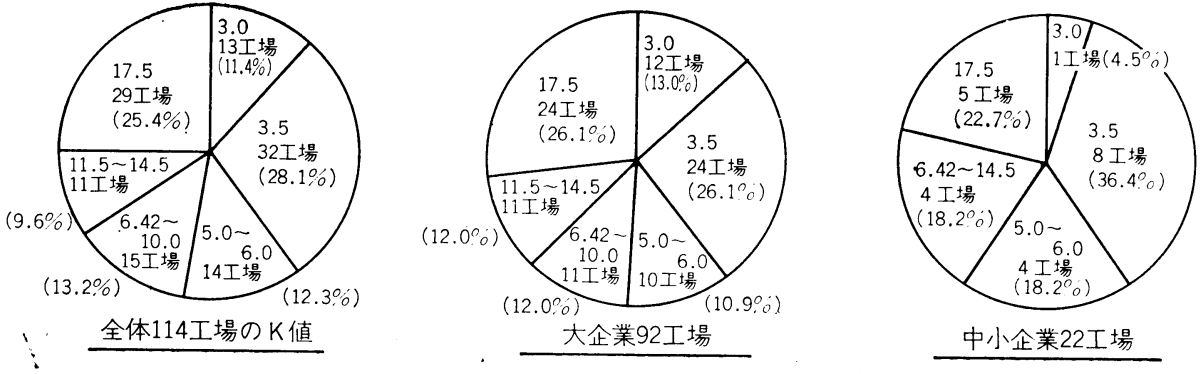

図 2 現在値のK值の分布状況

表 2 硫黄酸化物の総量規制適用工場

\begin{tabular}{|c|c|c|c|c|c|c|c|c|c|c|}
\hline \multirow{2}{*}{ 指 } & \multirow{2}{*}{ 定 回 } & \multirow{2}{*}{ 次 } & \multirow{2}{*}{ 指定年月 } & \multicolumn{2}{|c|}{ 指 定地 域 数 } & \multicolumn{2}{|c|}{ 適用工場 数 } & \multirow{2}{*}{\multicolumn{3}{|c|}{$\begin{array}{c}\text { 新規適用の内訳 } \\
\text { 都府県名と工場数 }\end{array}$}} \\
\hline & & & & 新 規 & 累 計 & 新 規 & 累 計 & & & \\
\hline 第 & 1 & 次 & $49-11$ & 11 & 11 & 35 & 35 & $\begin{array}{l}\text { (静岡21) } \\
\text { (大阪 } 7 \text { ) }\end{array}$ & $\begin{array}{l}\text { (東京 } 4 \text { ) } \\
\text { (兵庫 } 2 \text { ) }\end{array}$ & （千葉 1 ) \\
\hline 第 & 2 & 次 & $50-12$ & 8 & 19 & 4 & 39 & （大阪 1） & （兵庫 2 ) & (山口 1 ) \\
\hline 第 & 3 & 次 & $51-9$ & 5 & 24 & 5 & 44 & （埼玉 5 ） & & \\
\hline
\end{tabular}

\subsubsection{K 值規制}

$\mathrm{K}$ 值規制は第 1 次, 第 2 次規制までは指定地域制で 指定された地域にのみ適用されていたが，第 3 次から は全国のばい煙発生施設を対象に適用されることにな
った。そして $\mathrm{K}$ 值は地域の污染状況によってランク分 けされていて, 昭和 43 年 12 月第 1 次規制 ( 3 ランク) から昭和51年 9 月第 8 次規制 (16ランク) に至る改定 で逐次規制值が緟しくなってきている。

また, 特に高污染地域については, 地域を指定して 
（現在 28 地域）一般排出壆售とは別に，新しく設置す る施設に限って楜用されるより喛しい特別排出基準 (1〜3) ランクが設定されている。

アンケート調查の集計 114 工場における $\mathrm{K}$ 值の適用 推移を図 1 に示す。第 2 次規制までは指定地域制であ ったので，集尌工場のうち 46 工場のみが適用対象と なっていたが，第 3 次規制からは全国の施設に適用さ れることになり、集計工場のすべてが適用を受けるこ とになった。現在の集計工場 $\mathrm{K}$ 值分布を図 2 に示した。

\subsubsection{2 総量規制}

硫黄酸化物の総量規制は昭和 49 年 11 月の第 1 次指 定 (11地域) から昭和51年 9 月の第 3 次指定までに, 24地域に適用されるようになっている。

集计 114 工場のらち総量規制の適用を受けている工 場の推移は，表 2 および図 3 亿示した通りである。

現在総量規制の適用を受けている工場の割合は，図 4 に示すよらに全体の $38.6 \%$ となっている。

\section{1 .2 ばいじん}

ばいじんについては，ばい煙発生施設の種類と規模 (排出ガス量 $\mathrm{Nm}^{3} / \mathrm{h}$ ) ごとに全国一律の排出濃度基準が 定められているが，特に高污染の特定地域（現在 9 地

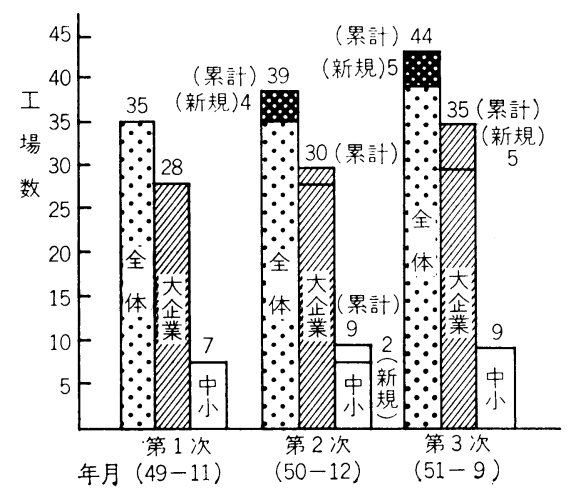

図 3 国の $\mathrm{SO}_{x}$ 総量規制を適用されている工場数 の推移
域）では、新設の施設に限って適用される簪しい值の 特別排出基準が別に定められている。アンケート調査 時の規制（昭和 46 年制定）はその後改定されて, 昭 和57年 5 月 28 日に新排出基準が公布されている。

\subsection{3 窒素酸化物 $\left(\mathrm{NO}_{x}\right)$}

\subsubsection{1 排出濃度規制}

窒素酸化物についても，ばい煙発生施設の種類と規 模（排出ガス量 $\mathrm{Nm}^{3} / \mathrm{h}$ ) ごとに全国一律の排出濃度 基準が定められ。昭和 48 年 8 月の第 1 次規制から昭 和 54 年 8 月の第 4 次規制と逐次規制対象施設 の範囲 （種類と規模）を拡大するとともに, 規制值も曒しく 改定されてきている。そして, 改定の都度その時点か ら新たに設置する施設と, 既に設置されている施設と に区分した 2 種類の排出基準が定められてきている。 そのほか第 3 次規制以前に設置された液体然料ボイラ 一については，排煙脱硫装置の有無により区分した 2 種類の排出基準が定められている。

\subsubsection{2 総量規制}

硫黄酸化物と同様に，排出濃度による規制では環境 基準が維持できない高污染地域については, 地域を指 定して総量規制を導入する政令が昭和 56 年 6 月 2 日 に公布された。そして東京, 神奈川, 大阪の 3 地域が 指定されて，57年にそれぞれ具体的な削减計画と規制 值が告示されている。

\section{2 自治体の上乗せ規制}

\section{2 .1 公害防止条例, 行政指導, 協定}

国の定める排出規制では環境基準の達成が困難な地 域に㧧いては, 自治体の条例, 行政指導, 公害防止協 定等によって上乗せ規制が行われている。上乗せ規制 には排出濃度による方法と, 排出総量による方法とが ある。

\section{2 .2 公害防止協定の締結推移}

公害防止協定で大気污染物質の排出規制について取 り決めを行っている工場数は，図 5 に示すように $58 \%$ に及んでいる。また，年次別の協定締結推移は図 6 に
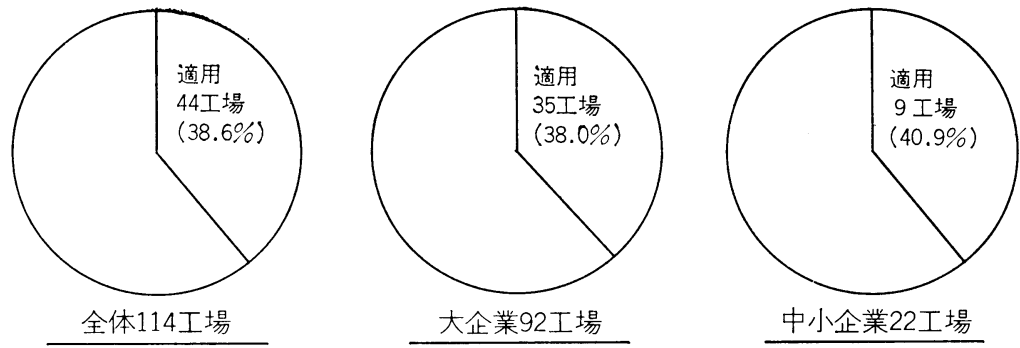

図 4 国の $\mathrm{SO}_{x}$ 総量規制を適用されている工場数（現在） 
示すように, 46 年頃から毎 年増加して 50 年がピークと なり，集計工場全体の $50 \%$ 近くに達している。

2.2.3 濃度規制による上 乗せ

条例，行政指導および協定 により, 排出濃度での上乗せ 規制を受けている工場の現状 は図 7 に示す通りである。ば いじんについて上乗せ規制を 受けている工場が多く, その 中でも重油ボイラーは集計工 場の約 $40 \%$ が適用を受けてい る。 $\mathrm{NO}_{\mathbf{x}}$ については重油ボ イラーに 17 工場が上乗せ規 制を受けている。有害物質に ついては $\mathrm{H}_{2} \mathrm{~S}$ が 8 工場, $\mathrm{Cl}_{2}$ が 5 工場, $\mathrm{HCl} \mathrm{が} 2$ 工場, CO ほかの物質について 3 工 場が規制を受けている。

\subsection{4 総量規制による上} 乗せ

条例, 行政指導および協定 により, 総量規制での上乗せ を受けている工場は図8 に示 す通りである。

硫黄酸化物について上乗せ 規制を受けている工場が多く， 工場全施設の排出総量に対す る規制を受けているところが 25工場で, 集計工場全体の約 22\%となっている。

\section{3. 対策の推移について}

\section{1 アンケート集計工場}

対策の推移については大企 業 92 工場中小企業 27 工場 $\sigma$ 回答を得たが，大企業を回収 ボイラーや石灰焼成炉のばい じん対策が必要な「R B りり, すなわち化学パルプ製造工程を有する工場と, そうで ない「RBなし」に分類して集計して考察した。大企 業のこの区分を企業形態別区分と呼称して記述した。 それぞれの昭和 55 年度の最終製品生産能力は表 3 の 通りである。

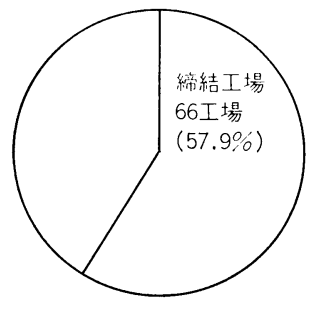

全体114工場

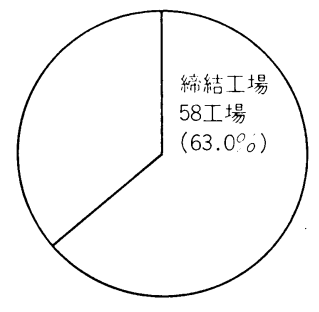

大企業92工場

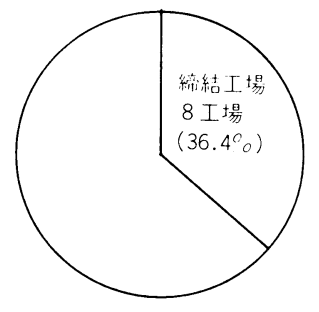

中小企業22工場
図 5 公害防止協定を締結している工場数（現在）

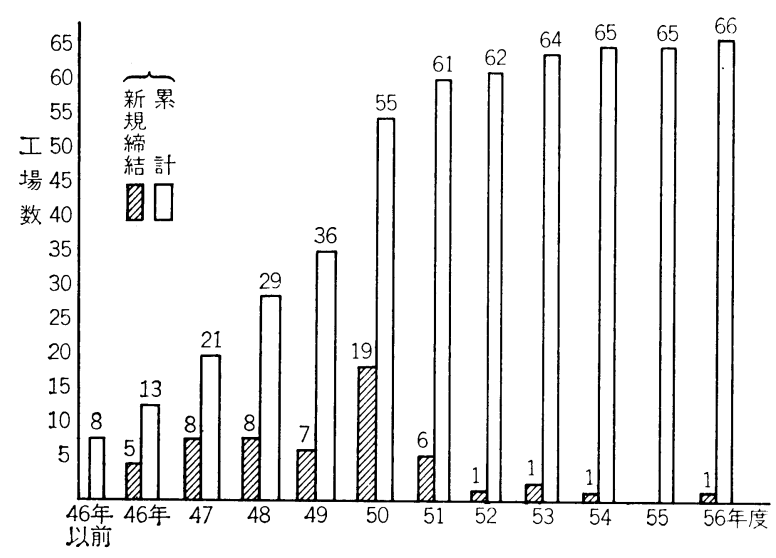

図 6 公害防止協定締結工場数の推移

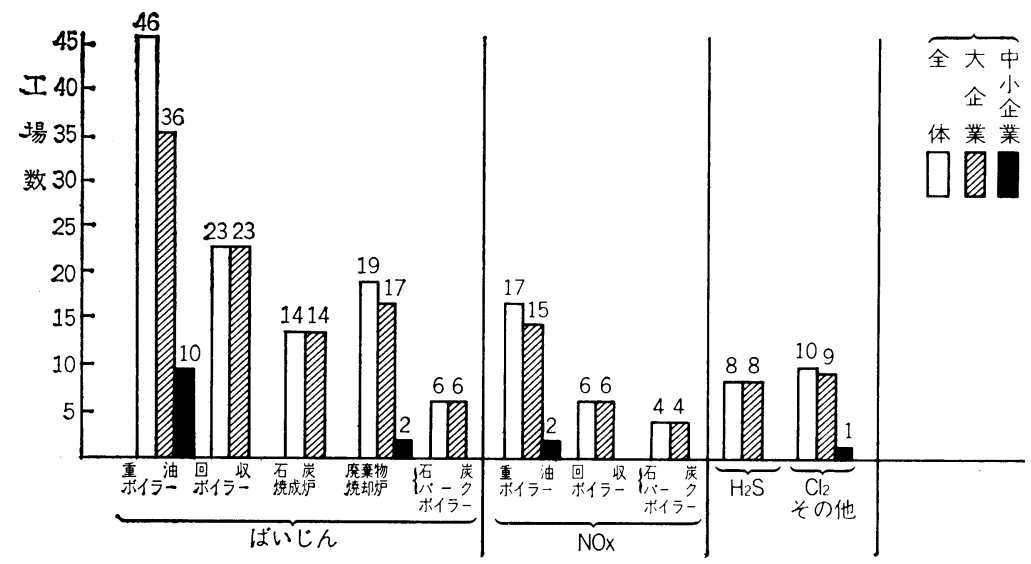

図 7 条例, 協定, 行政指導で排出濃度による上乗せ規制を受けている工場数 
いじル， $\mathrm{NO}_{x}$, 粉じんその他 上, 対策 (污染物質) ごしの 牛度则投資嗺推移を示した。 投資额のピークは50外淓で

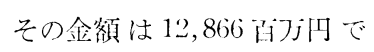
あり，そり約 70 号が $\mathrm{S}()_{x}$ 刘 策で，K佰籍 7 次規制や総! 規制に対念与るため, 脱硫装 置を㤈心多額の投资が行わ れている。その後 51 ～ 53 作 度と一娍少した投資额が， 54〜55华度には再上界してい る。これはТ埸の盺没もあっ たが, 脱硫装型の增加, 不岑 䡮換等が主:装因上洗えられる。

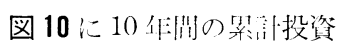
額の対策则 (活染物質则) 比 率を示した。アンケート们箈 には粉じんその他対策につい ては，必ずしもすべての工埸 が報留していないようにも桨 えられるので，笑態は多少異 なるかも知れ双が，紙パルプ 丁埸の大父刘策の主:体は $\mathrm{SO}_{x}$ 対策 (約 $52 \%)$ 上, ばいじん

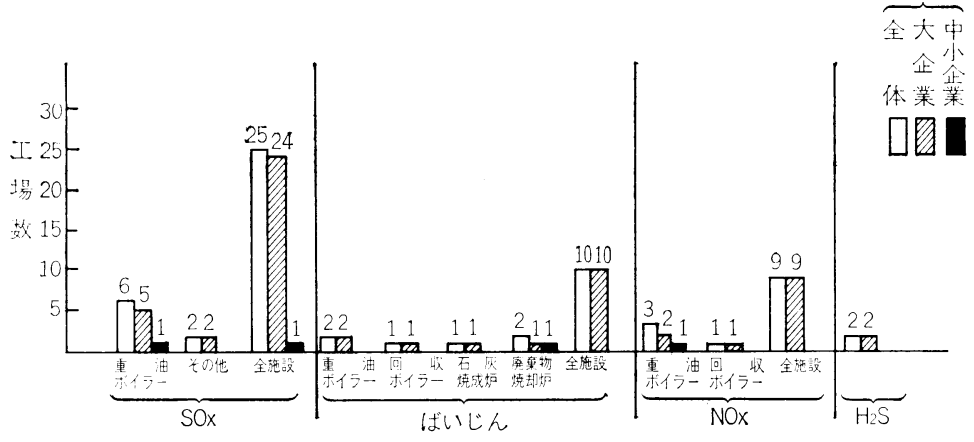

図 8 条例, 協定, 行政指導で総最規制による上乗せを受けている工場数

対策 $(40 \%)$ である。また，

各年荄での対策则比率推移は，図９に付記した通りで ある。

\section{3 対象施設別の投資額推移}

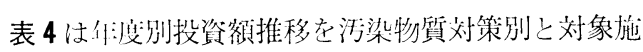

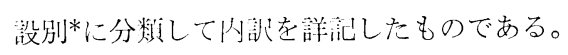

図 11 は 10 作泪の累浙資額の対象施設別の比率を 示した。而洲ボイラーが $54.5 \%$ で回収ボイラーの 33 \%と合汁して $87.5 \%$ となり，大気対策の主体をらし ている。

\section{4 企業規模, 形態別の投資額}

企業规模，形態别の投資額罚汁は表 5 の通りである

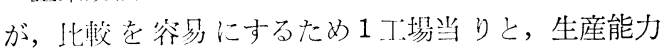

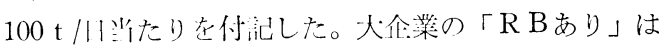

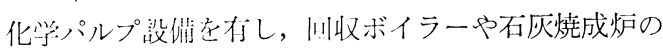
ばいじん対策等の投資が必留なことから，1工場当た り扩よび生应能力当たりの投資額は大きい。中小企業 での生産能力当たりの投資額が小さいのは，1）化骂

パルプ設㫦を持たない，2）規制值の厳しい大規模施 設が少ない，3） $\mathrm{SO}_{x}$ 対策には脱硫装置を設置しな いで，高価な軽質油で対応している，例がある等によ るものと思われる。

表 6 はさらに活染物質対策別および対象施設別に队 訳を分類詳記した。「大企業RBあり」の工場は $\mathrm{SO}_{x}$ 対策に $46.4 \%$ ，ばいじん対策に $46.6 \%$ と雨対策の投 資額がほぼ同程度であるが，「大企業 R B なし」では $\mathrm{SO}_{x}$ 対策のウエイトが $73 \%$ と大り。中小企業では $\mathrm{SO}_{x}$ 対策が $60 \%$ を占めている。

\section{5 污染物質別対策投資の装置方法の状況}

\subsection{1 $\mathrm{SO}_{x}$ 対策}

表 7 に $\mathrm{SO}_{x}$ 対策投資額を機種別，対象施設別に分 類して示した。図 12!と図 13 は対策の方法機種別構成 比率と, 対象施設別の構成比率る示した。 $\mathrm{SO}_{x}$ 対策 の投資額で方法機種別では脱硫装置が $80 \%$ 強を占め, 煙道煙突関係が $14 \%$ である但し，件数では煙道熤

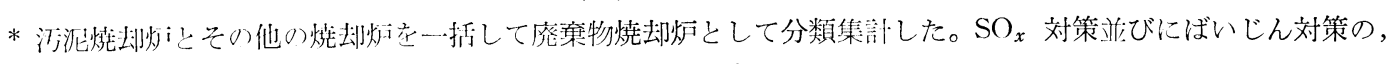
その他の施没にはバーク・石炭等の测体燃料ボイラーを含んでいる。 


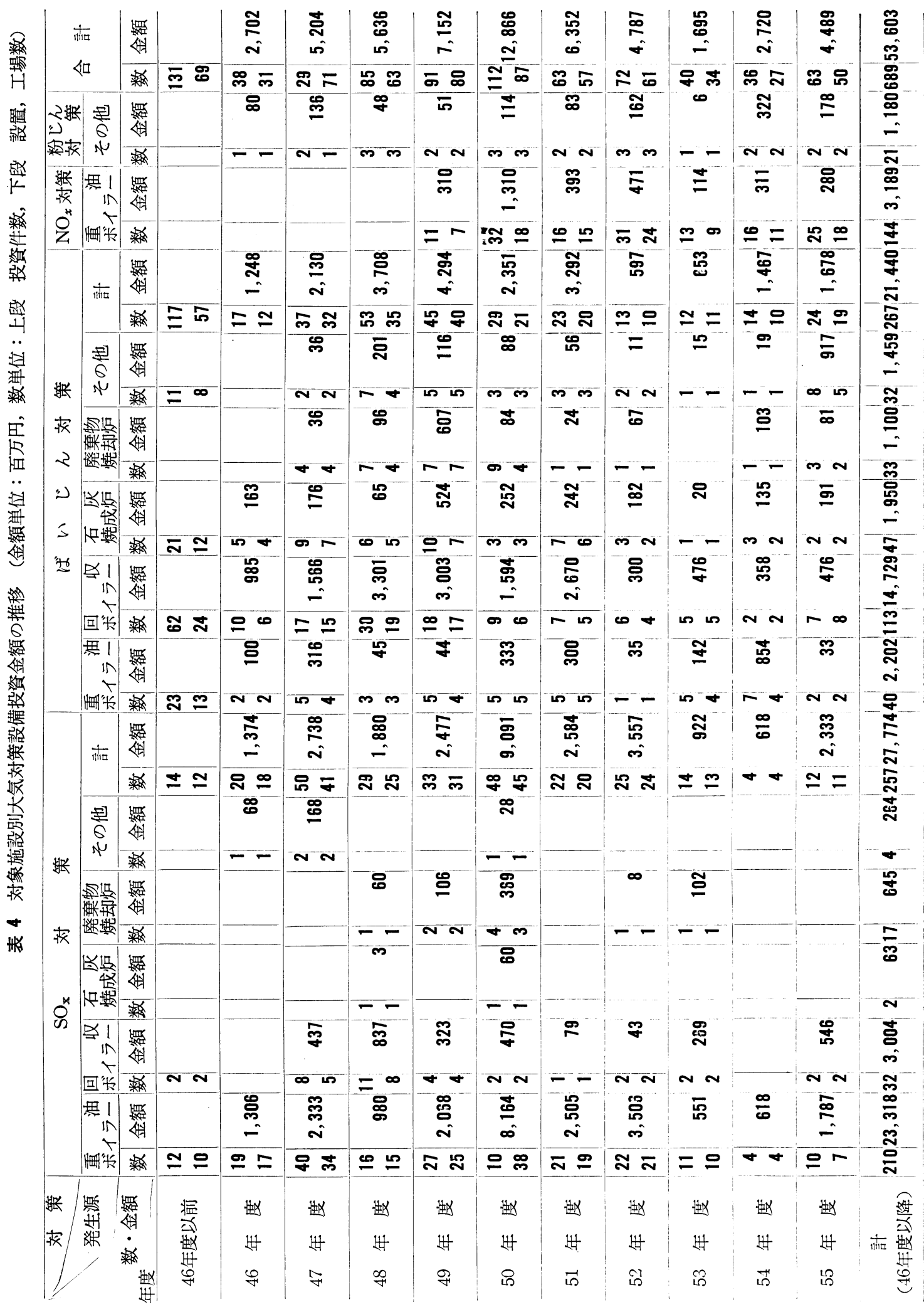




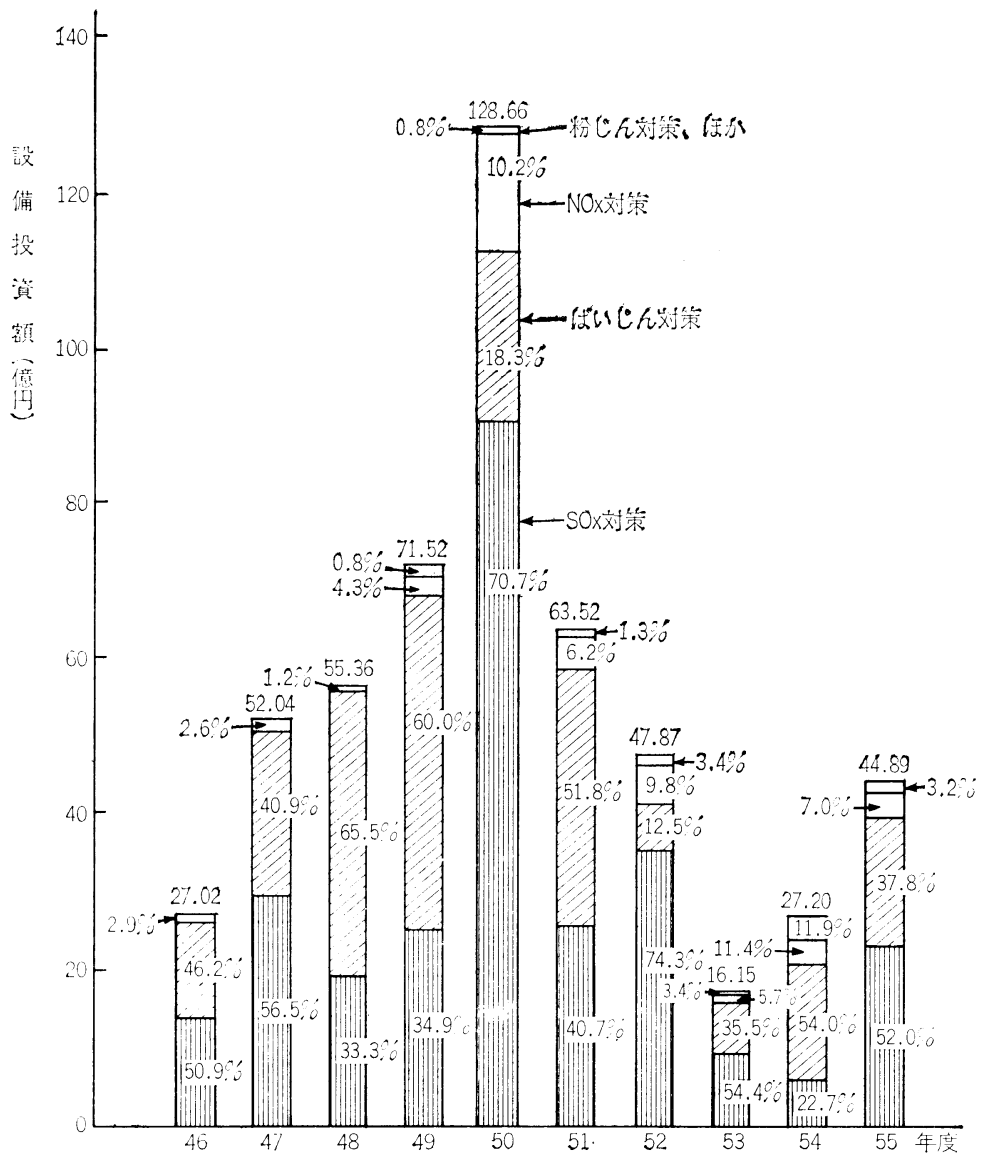

図 9 大気污染対策設借投資額の推移 (対策別)

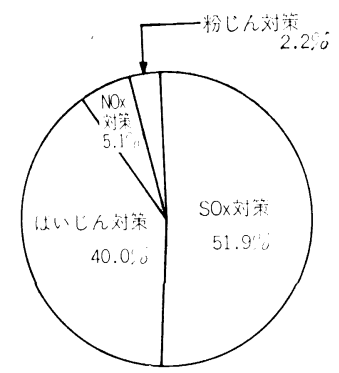

図 10 大気対策累归投資額の対策別比率

突関倸が 61 作で脱硫装巽の約 $1 / 2$ に近く，K 值対策 として高煙突化もかなり採用されている。対象施設別 には重油ボイラーーの投資が圧倒的に多：く $85.7 \%$ と なっている。

また, $\mathrm{SO}_{x}$ 対策投資額と俳数の推移は, 図 14 に示 すように 50 年度がピークで突出している。これは国 の総量規制とそれに追従した自治体による協定, およ びK值の強化に刘忘するための脱硫装置の投資が主:休

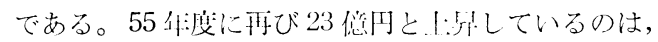

表 5 大気対策累計投資額（百万円）

\begin{tabular}{|c|c|c|c|c|}
\hline & 総＼cjkstart額 & $\begin{array}{l}1 \text { 工場 } \\
\text { 当たり }\end{array}$ & 能力 $100 t /$ 山当り \\
\hline \multirow{3}{*}{$\begin{array}{l}\text { 大 } \\
\text { 企 } \\
\text { 業 }\end{array}$} & R Bあり & 42,041 & 1,051 & 119 \\
\hline & R Bなし & 10,383 & 200 & 71 \\
\hline & 小 & $(52,424)$ & $(570)$ & (105) \\
\hline \multicolumn{2}{|c|}{ 中小企業 } & 1,179 & 44 & 29 \\
\hline 合 & 計 & 53,603 & - & - \\
\hline
\end{tabular}

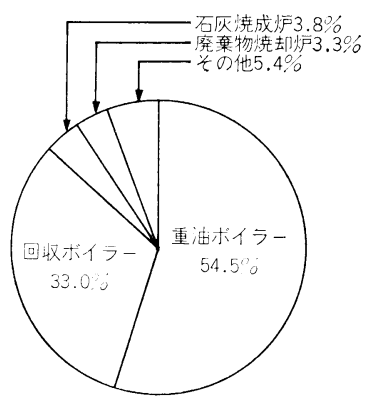

図 11 大気対策投資额の施設放比淬 
慗

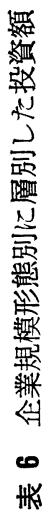

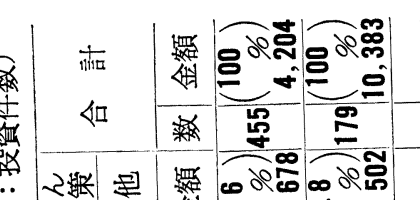

弪

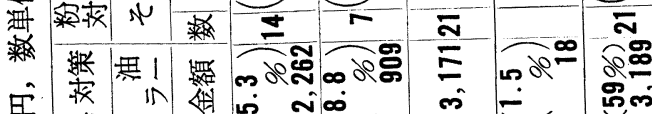

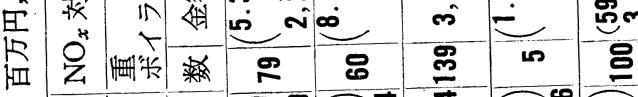

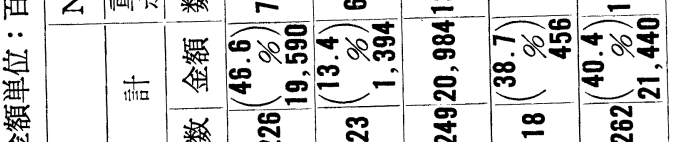

速
告

רై

|

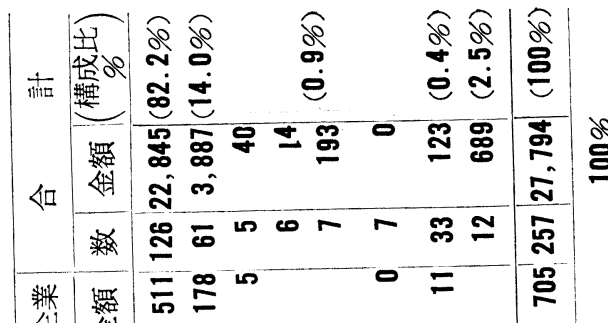

स进 的

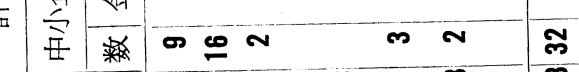

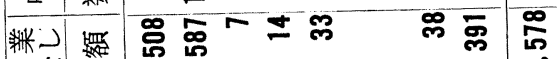
16 से एक ए Kณ म 料。器 ปั

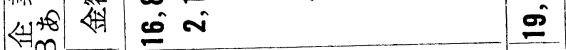

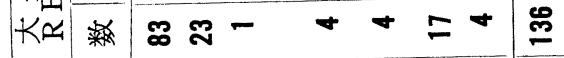

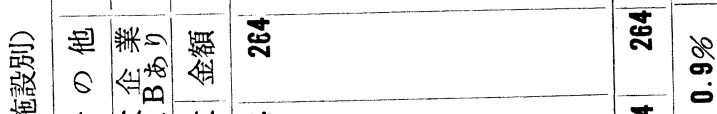

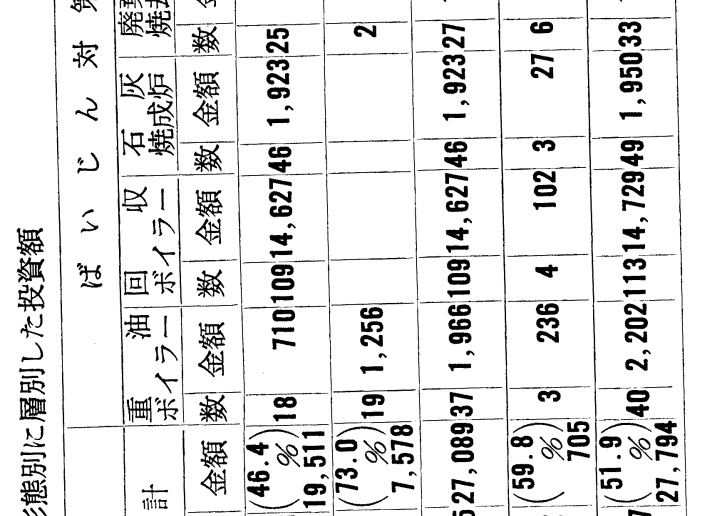
湾

宊

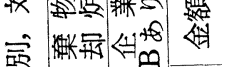

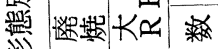

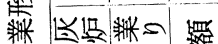

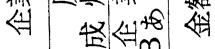

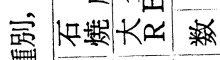
造 政 解

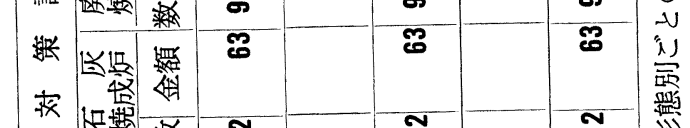

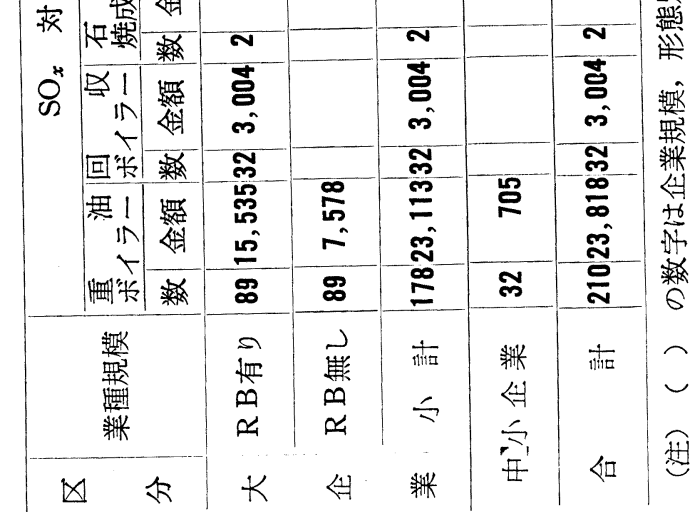
$r<\|^{+\infty}<$ 回”负 $K$ 幽

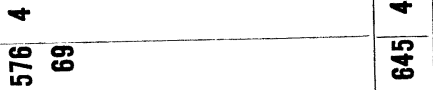

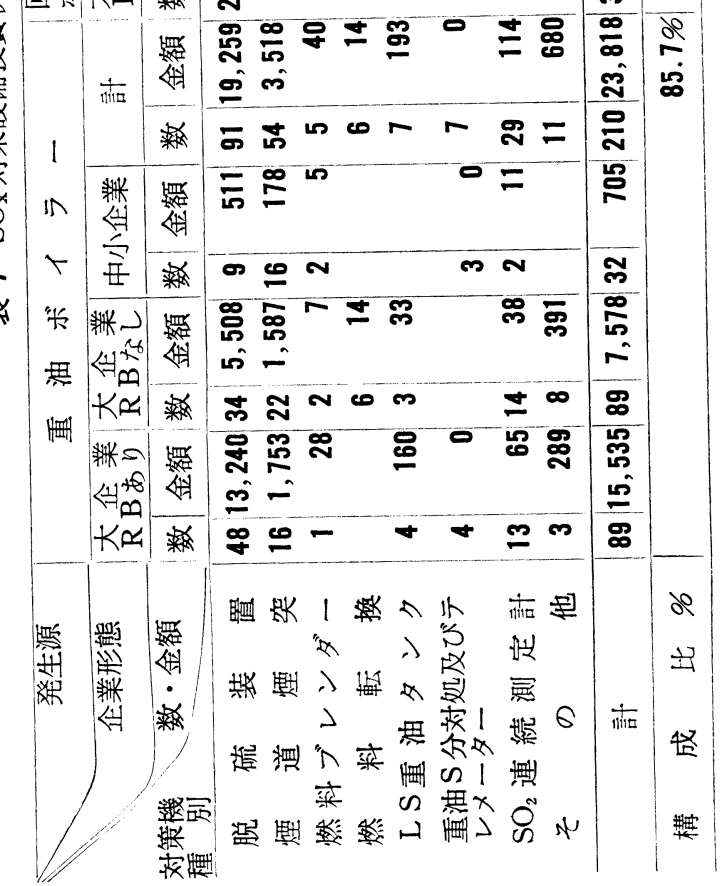




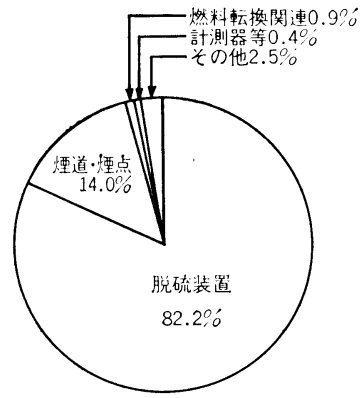

図 $12 \mathrm{SO}_{x}$ 対策設哄の队容權成

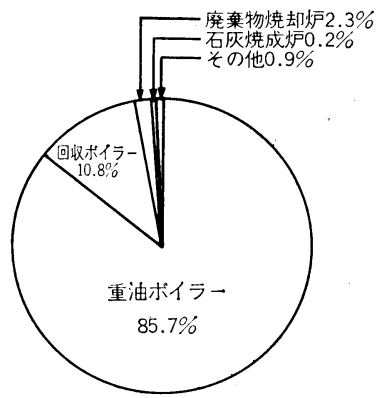

図 $13 \mathrm{SO}_{x}$ 対策対象施設の構成

表 8 ばいじん対策の設借投資額（機種別・企業規模別・対象施設）昭和46〜55年度

（金額単位：百万円，数単位：投資件数）

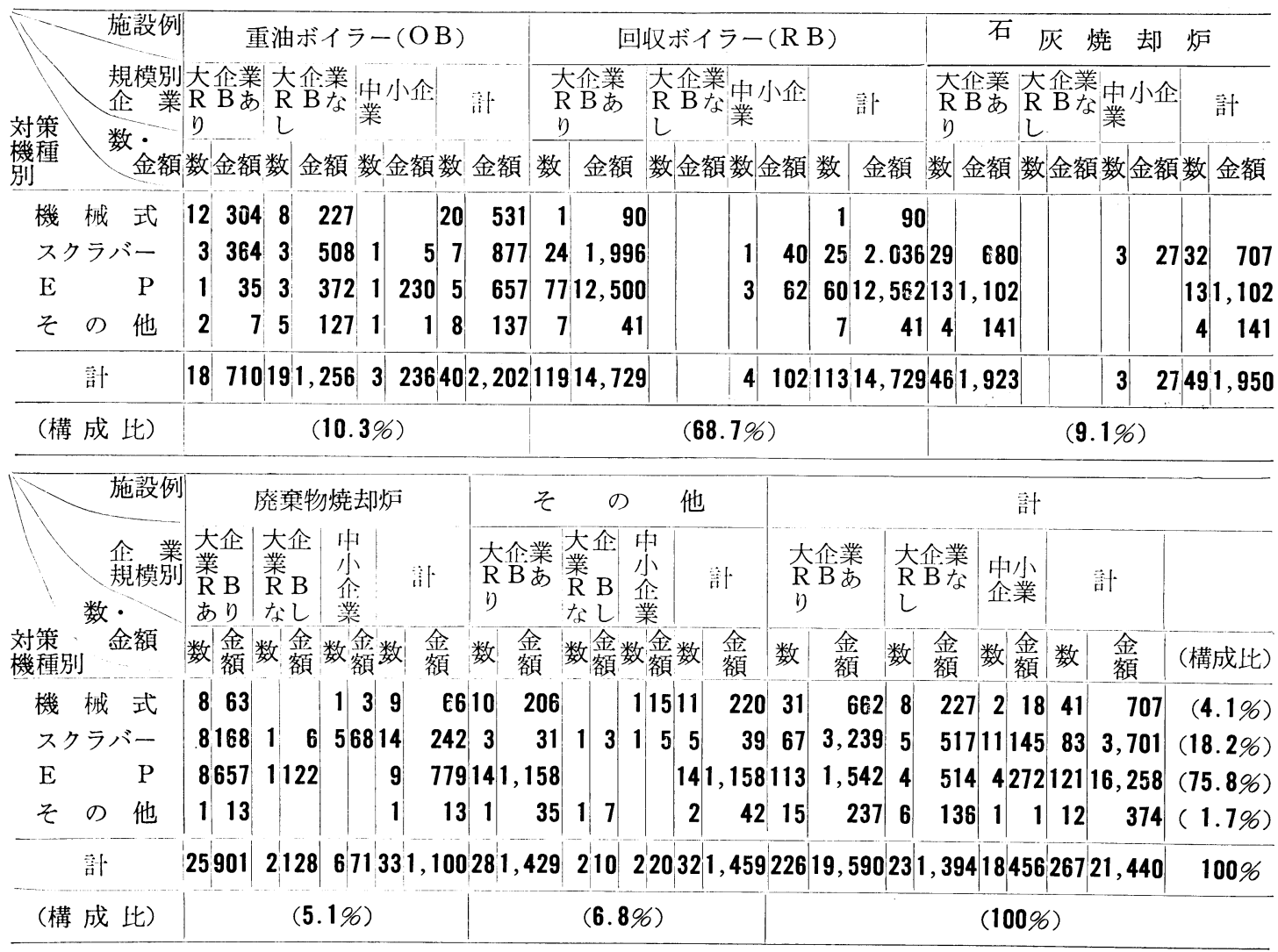

エネルギー事情を反映して脱硫装置の件数が増加した ことによる。

\section{5 .2 ばいじん対策}

表 8 にばいじん対策の絮计投資額を機程別，対象施 設別に分類して示した。

図 15 にばいじん対策の機秏別構成此率を示したが， 電気集じん装置が約 $3 / 4$ を占めている。図 16 には対 昭和 59 年 (1984) 5 月
象施設別の構成比率を示したが回収ボイラーが約70\% を占めている。しかし，ばいじんについては回収ボイ ラー, 石灰焼成炉は企業形態によって有無があり, 図 17 のように対象施設別の構成比は大きく変わる。

また，ばいじん対策投資額と件数の推移を図 18 に 示したが，ピークは 49 年度で, $\mathrm{SO}_{x}$ の場合と異なり 48 年度から 51 年度にかけてなだらかな山形を示して 
いる。これらは 46 年 6 月の法規制設定後 $3 \sim 4$ 年の間 に, 上乗せの条例, 協定が逐次発効し, これに対応す るための電気集じん装置の改造, 増強やスクラバー設 置が相次いだためである。49 年度を中心に廃棄物焼 却炉が多く新設され，その集じん装置の設置も含まれ ている。54〜55 年度に投資額が再上昇しているのは, 電気集じん装置の更新と石炭ボイラー復活に伴う除じ ん設備等による。

\subsubsection{No $x$ 対策}

表 9 に $\mathrm{NO}_{x}$ 対策の累計投資額を方式別に示した。

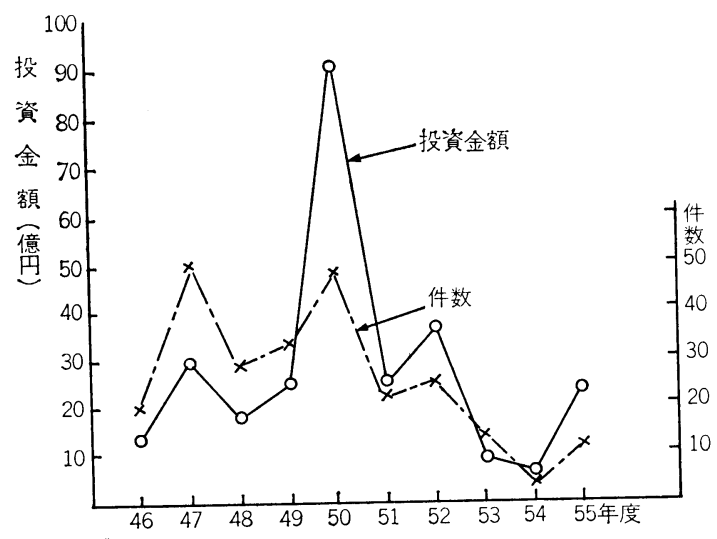

図 $14 \mathrm{SO}_{x}$ 対策設備投資金額と件数の推移

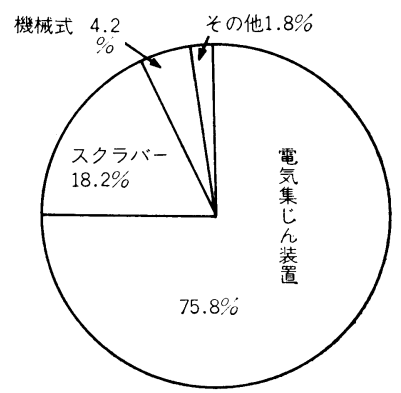

図 15 ばいじん対策設備の内容構成
対策施設は重油ボイラーのみであり, 方式としては低 $\mathrm{NO}_{x}$ チップ, 低 $\mathrm{NO}_{x}$ バーナー, 二段然焼, 排ガス 再循環などの燃焼改善の方法がとられている。

$\mathrm{NO}_{x}$ 対策投資額と件数の推移を図 19 に示した。投 資は第 1 次規制に対応する 49 年以降で, 規制が 既設 ボイラーに適用された 50 年度がピークである。その 後も第 $2 \sim 4$ 次と相次ぐ規制強化に対処するため,

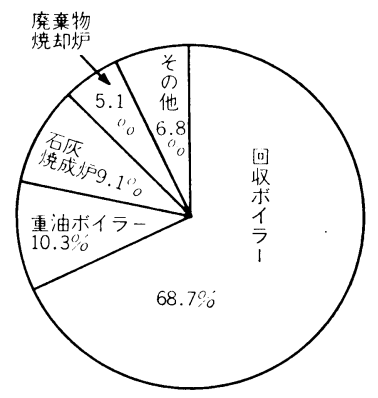

図 16 ばいじん対策対象施設の構成

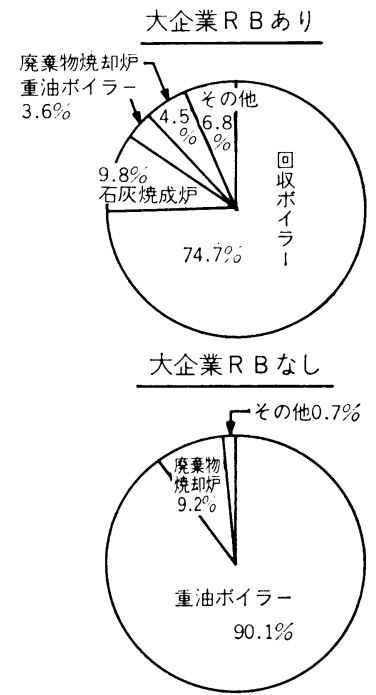

図 17 企業形態別対象施設の構成（ばいじん対策）

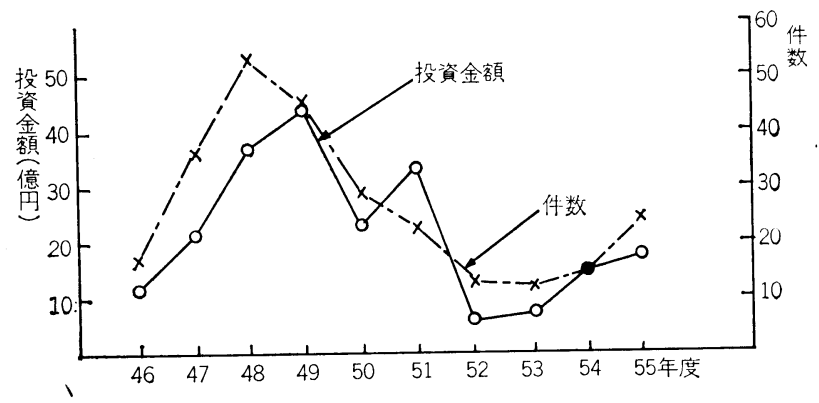

図 18 ばいじん対策設借投資金額と件数の推移 
低 $\mathrm{NO}_{x}$ バーナー棌人を中心に対忍されている。

\subsection{4 粉じん，その他対策}

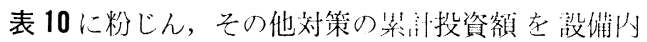
容で分類して示した。投資はすべて大業で, 中小企 業の報儌はなか一た。粉じん対策が主:体（約79\%) で，そのうちフェン人が59\%と最も投資額が大きく， しかも，1俳腹たり投資額も多額である。粉じん対策 でフェンス, 教水設化以外の 主な队容は，チップヤードま わりの折效策が俳数としては 多く，洗のチップヤード粉じ ん対策に関するものもある。 その他の対策については, 晒 工程の $\mathrm{ClO}_{2}$ 排ガススクラバ 一設置, 石灰焼成炉の集じん 設備, 白煙対策等が主なもの である。但し，回答数が極
めて少ないため今回は報售されていないが，このほ かにもかなりの渚対策が実施されていると推祭され る。

投資额と作数の推移を図 20 に六した。姙述の则く 们签数が少なく報售もれもあって，実際にはまだかな

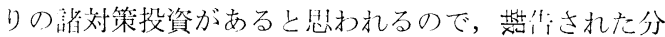
の推移走示すによどめて論評はさしひかえる。

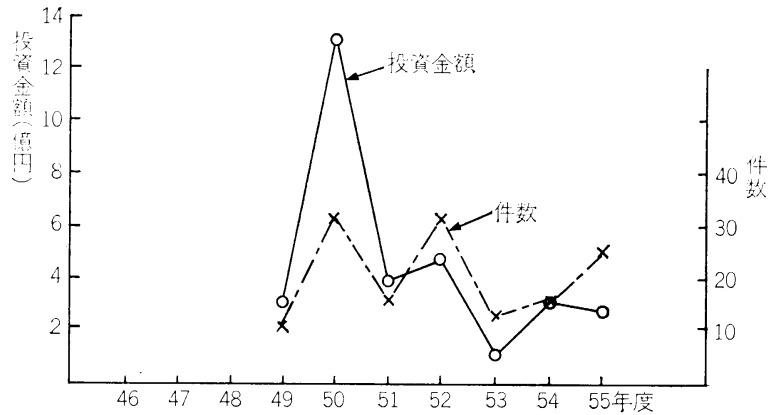

図 $19 \mathrm{NO}_{x}$ 対策設備投資金額と件数の推移

表 $9 \mathrm{NO}$ x 対策設俏投資状洗（46〜55年度合计）重油ボイラー（百万円）

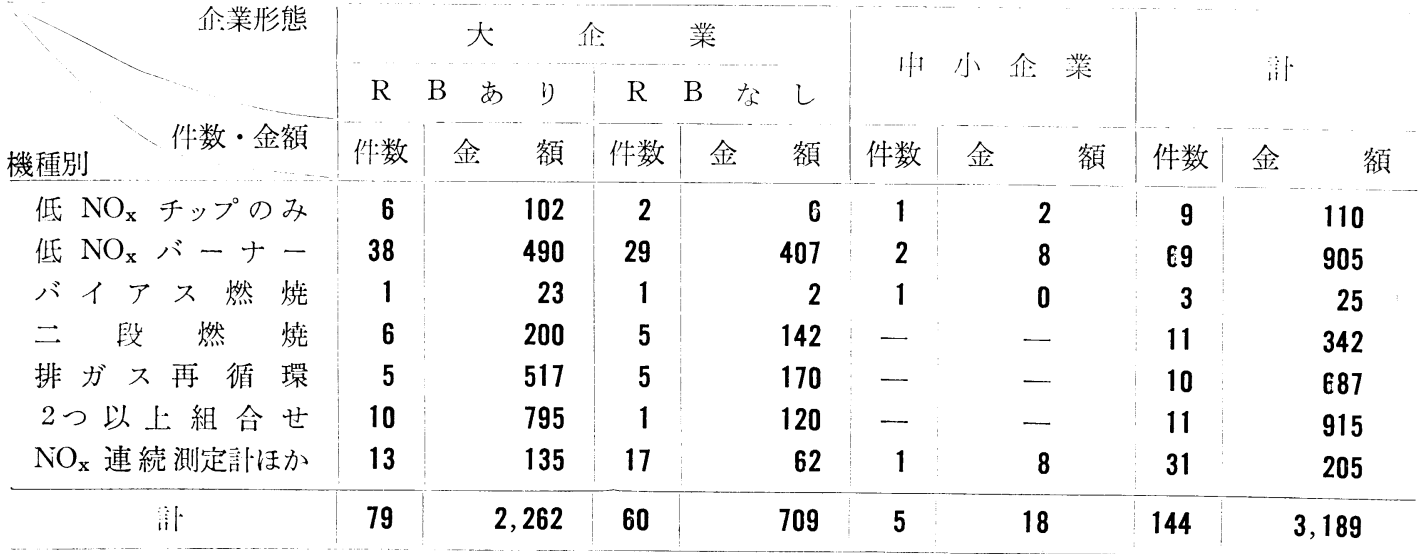

表 10 粉じん対策，その他対策の投資状況 （百万円）（46～55年度合訣） 企業規模形態

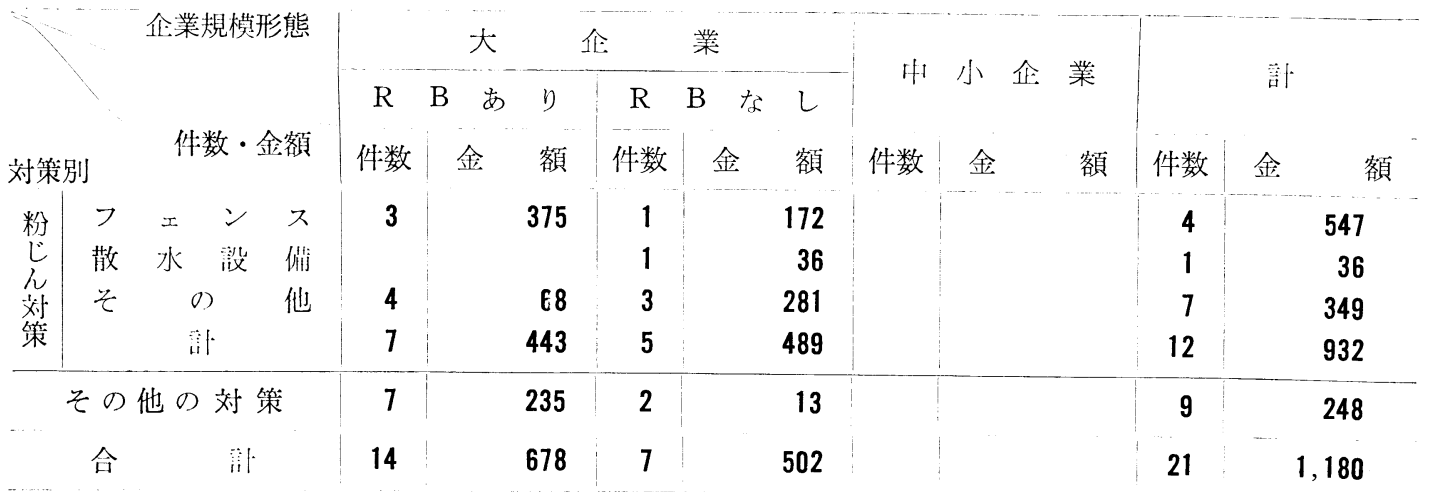

昭和 59 年 (1984) 5 月 


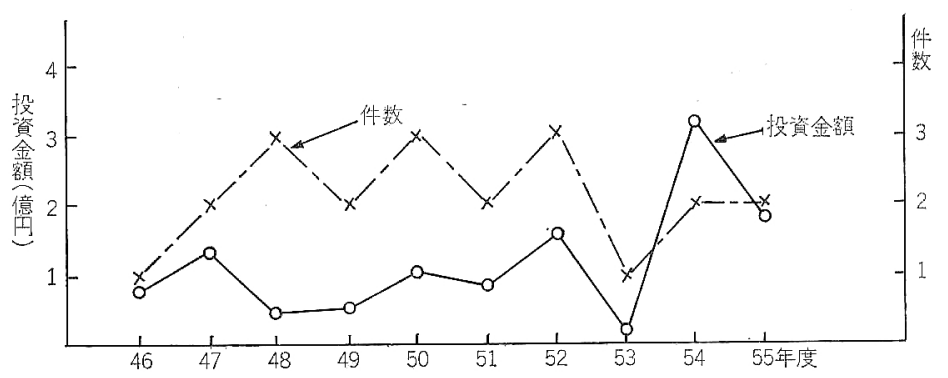

図 20 将じんその他対策設備投資金額と件数の推移

\section{4.おわりに}

大気污染対策の投資怊昭 50 年度がピークで，そ の後は漱減して 53 年度を底に丽び上昇傾向になって いる。これは第 7 次までの相次ぐK值改正や $\mathrm{SO}_{x}$ 総 量規制の镈入，あるい第 2 次までの $\mathrm{NO}_{x}$ 排出基準， 改正と，これらに追従しての自治体の上乘せに対姏す るための投資が 50 年頃に集中したことを示しており，
近年の投資額再上昇は省資源，尙エネルギーの面から， そして環境保全コストの面から設辁の改善，更新など に取り組まれていることによると䍐われる。今後は $\mathrm{NO}_{x}$ 総量規制の実施やばいしん排出基準の改定など の規制強化に刘処するため，また省エネルドーと環境 保全コストの面からも設储の改善と技術の開発に一層 の研究努加汃求め斿よう。

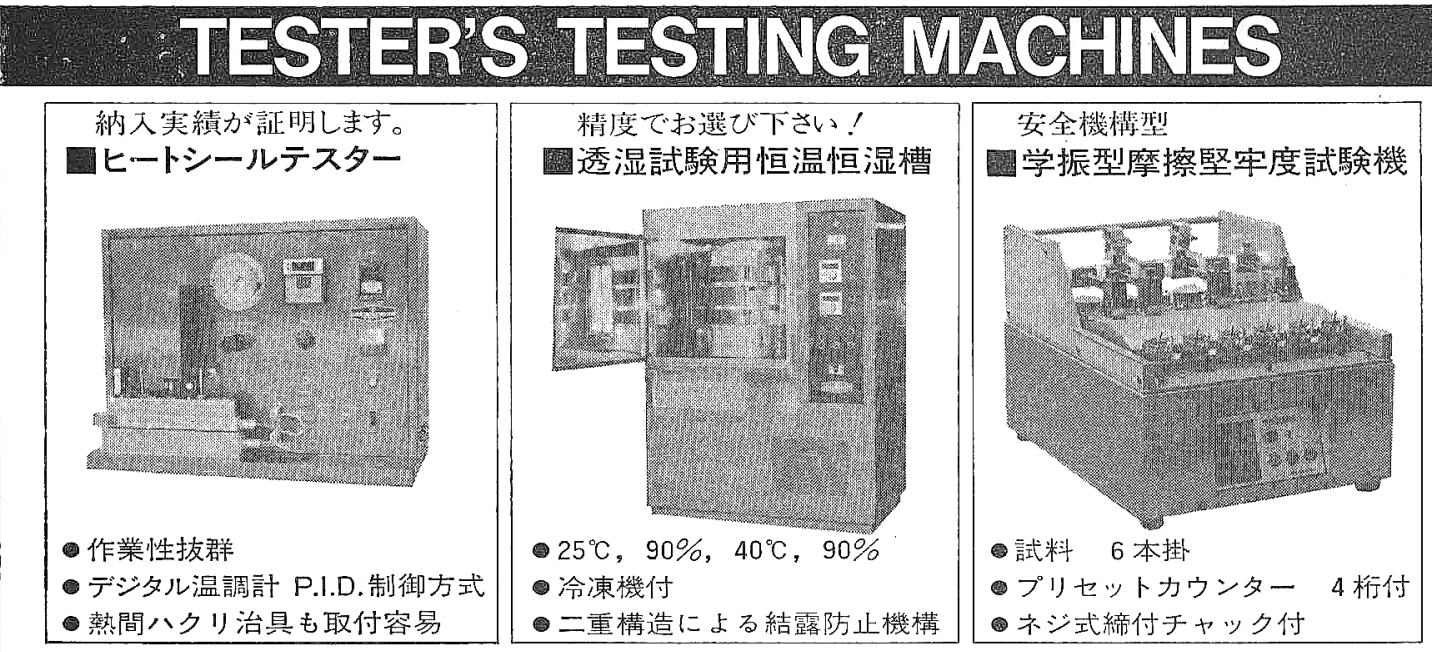

\section{営業品目}

プラスチック、ゴム試験機・紙、パルプ試験機・繊維 洤料、インキ試験機・ 理化学機器・特殊機器設計、製作

試験機・計測器のコンサルタント
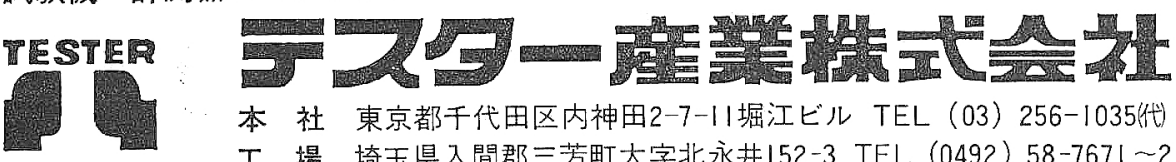

本 社 東京都千代田区内神田2-7-11堀江ビル TEL（03）256-1035(代)

工 場 埼玉県入間郡三芳町大字北永井152-3 TEL (0492) 58-7671 -2 